Jurnal Ilmiah Dikdaya, 9(1), 98-103

ISSN 2088-5857(Print), ISSN 2580-7463 (Online)

Rosmiati, Zuhri Saputra Hutabarat

\title{
Peningkatan Mutu Ipteks Kewirausahaan (IbK) Pada Siswa Kelas XII SMAN 2 Kota Jambi
}

\author{
Rosmiati $^{1}$, Zuhri Saputra Hutabarat ${ }^{2}$
}

\begin{abstract}
Abstrak: Mengingat bahwa IbK suatu saat harus mandiri dan operasionalnya berkelanjutan, maka IbK diberi akses seperti halnya nirlaba kemudian diberi tugas ekstra untuk mampu menjadi unit profit dengan memanfaatkan sumber daya manusia dan fasilitas yang dimiliki. Dalam upaya menciptakan wirausaha baru mandiri yang berbasis ipteks diharapkan sesuai dengan bidang ilmunya, program IbK dapat dilaksanakan dalam bentuk pelatihan kewirausahaan, menempatkan siswa untuk melaksanakan magang pada perusahaan yang mapan/unit-unit usaha/IbIKK di Sekolah tersebut dan memfasilitasi siswa berwirausaha. Pelatihan dilaksanakan untuk memberikan pengetahuan kewirausahaan, mendorong tumbuhnya motivasi berwirausaha, meningkatkan pemahaman manajemen (organisasi, produksi, keuangan, dan pemasaran) serta membuat rencana bisnis atau studi kelayakan usaha. Sungguh tak terpikirkan, anak-anak diajarkan menjadi pegawai di perusahaan, tapi siapa yang mendirikan perusahaan itu jika bukan wirausahawan. Anak-anak, remaja sangat membutuhkan cukup waktu dengan orang dewasa agar dapat mendukung, mendorong serta membantu mereka mencari tahu siapa mereka, bagaimana dunia bekerja, dan apa peran mereka dalam masyarakat.
\end{abstract}

Kata kunci: peningkatan mutu, ipteks

Abstract: Given that IbK must someday be independent and operationally sustainable, then IbK is given access just as non-profits are then given an extra task to be able to become a profit unit by utilizing human resources and facilities owned. In an effort to create independent science and technology-based new entrepreneurs, it is expected that in accordance with their fields of knowledge, the IbK program can be carried out in the form of entrepreneurship training, placing students to carry out internships in established companies / business units / IbIKK in the School and facilitating student entrepreneurship. The training is carried out to provide entrepreneurial knowledge, encourage the growth of motivation for entrepreneurship, improve management understanding (organization, production, finance, and marketing) and make business plans or business feasibility studies. It is unthinkable, children are taught to be employees in the company, but who founded the company if they were not entrepreneurs. Children, teenagers, really need enough time with adults to be able to support, encourage and help them find out who they are, how the world works, and what their role is in society.

Keywords: quality improvement, science and technology

\section{PENDAHULUAN}

Ipteks bagi Kewirausahaan (IbK) merupakan program baru di DP2M Dikti yang dirumuskan pada tahun 2009. Pada prinsipnya program I bK mensubstitusi program sejenis sebelumnya, yaitu Pengembangan Budaya Kewirausahaan di Perguruan Tinggi (PBKPT), yang dirumuskan dan direalisasikan sejak tahun 1997. Program PBKPT yang dilaksanakan secara parsial tanpa adanya sinergi di antara setiap program (KWU, KKU, MKU, KBPK dan INWUB), menyebabkan tidak dapat mencapai misinya membentuk wirausaha baru dari kampus. Di samping itu, PT umumnya telah memiliki mata kuliah wajib atau pilihan Kewirausahaan dan Unit Penempatan Tenaga Kerja. Oleh karena itu, DP2M memandang perlu untuk merumuskan suatu program dengan misi yang sama, yaitu menghasilkan wirausahawirausaha baru dari kampus, namun mela lui program terintegrasi dengan kreasi metode diserahkan sepenuhnya kepada penyelenggara I bK. IbK hanya satu untuk setiap Perguruan Tinggi, dikelola di bawah LPM/LPPM/UPPM PT dengan melibatkan sejumlah dosen yang berpengalaman berwirausaha dari berbagai

\footnotetext{
${ }^{1}$ Dosen Pendidikan Ekonomi Universitas Jambi

${ }^{2}$ Dosen Pendidikan Ekonomi Universitas Batanghari Jambi
} 
disiplin ilmu. IbK melaksanakan pelatihan manajemen usaha bagi tenant dan sejumlah kegiatan kreatif lainnya untuk menghasilkan wirausaha baru yang mandiri berbasis ipteks. Untuk keperluan pembentukan dan peningkatan keterampilan menghasilkan produk, tenant melakukannya di program studi masing-masing. Dalam kegiatannya, IbK juga disarankan berkolaborasi dengan lembaga -lembaga yang terkait dengan pengembangan kewirausahaan termasuk IbIKK di PT masing-masing.

Kewirausahaan adalah kemampuan kreatif dan inovatif yang dijadikan dasar, kiat, dan sumber daya untuk mencari peluag menuju sukses (Suryana, 2006:2). Hisrich, Peters, dan Sheperd mendifinisikan: "Kewirausahaan adalah proses penciptaan sesuatu yang baru pada nilai menggunakan waktu dan upaya yang diperlukan, menanggung risiko keuangan, fisik, serta risiko sosial yang mengiringi, menerima imbalan moneter yang dihasilkan, sertra kepuasan dan kebebasan pribadi".

Kewirausahaan juga dapat didefinisikan sebagai "pengambilan risiko untuk menjalankan usaha sendiri dengan memanfaatkan peluang-peluang untuk menciptakan usaha baru ataudengan pendekatan yang inovatif sehingga usaha yang dikelolaberkembang menjadi besar dan mandiri dalam menghadapi tantangan persaingan.

Technopreneurship merupakan sebutan untuk para pelaku bisnis berbasiskan teknologi, mereka menghasilkan produk inovatif dengan penggunaan teknologi dalam setiap bisnisnya (Suhartanto \& Ary, 2010:xv).

Direktorat Riset dan Pengabdian Masyarakat (DRPM) melaksanakan suatu program dengan misi menghasilkan wirausaha-wirausaha baru dari kampus, melalui program terintegrasi dengan kreasi metode yang diserahkan sepenuhnya kepada perguruan tinggi melalui Program Iptek bagi Kewirausahaan (IbK). Setiap perguruan tinggi berhak mengelola lebih dari satu program IbK dengan melibatkan sejumlah dosen yang berpengalaman berwirausaha dari berbagai disiplin ilmu. IbK melaksanakan pembinaan kepada tenant melalui pelatihan manajemen usaha dan sejumlah kegiatan kreatif lainnya untuk menghasilkan wirausaha baru yang mandiri berbasis iptek. Tenant harus meningkatkan keterampilan dalam menghasilkan produk di program studi masing-masing. Pengelola Program IbK juga disarankan berkolaborasi dengan lembagalembaga yang terkait dengan pengembangan kewirausahaan, baik di dalam maupun di luar kampus, termasuk program Iptek bagi Kreativitas dan Inovasi Kampus (IbKIK) di perguruan tinggi masing-masing.

Misi program IbK adalah memandu perguruan tinggi menyelenggarakan unit layanan kewirausahaan yang profesional, mandiri dan berkelanjutan, berwawasan knowledge based economy. Program IbK harus mandiri dan operasionalnya berkelanjutan, sehingga IbK diberi peluang untuk mampu menjadi unit profit.

Dalam upaya menciptakan wirausaha baru mandiri yang berbasis iptek diharapkan sesuai dengan bidang ilmu pengusul. Program IbK dapat dilaksanakan dalam bentuk pelatihan kewirausahaan, menempatkan mahasiswa untuk melaksanakan magang pada perusahaan yang mapan/unit-unit usaha/IbKIK di perguruan tinggi tersebut dan memfasilitasi mahasiswa dalam berwirausaha. Pelatihan dilaksanakan untuk memberikan pengetahuan kewirausahaan, mendorong tumbuhnya motivasi berwirausaha, meningkatkan pemahaman manajemen (organisasi, produksi, euangan, dan pemasaran) serta membuat rencana bisnis atau studi kelayakan usaha. Kegiatan magang pada perusahaan/unit-unit usaha/IbKIK dilaksanakan untuk memberikan pengalaman praktis kewirausahaan kepada mahasiswa dengan cara ikut bekerja sehari-hari pada unit usaha tersebut. Mahasiswa yang telah mulai berwirausaha, mahasiswa Program Kreatifitas Mahasiswa Kewirausahaan (PKMK), Program Kreativitas Mahasiswa (PKM) lainnya, Program Mahasiswa Wirausaha (PMW), mahasiswa yang berminat dan sedang merintis usaha, dan alumni yang berminat atau baru merintis usaha bias menyempurnakan kegiatan kewirausahaan yang telah dilakukan sebelumnya, untuk meningkatkan usahanya. Pengelola Program IbK perguruan tinggi disarankan untuk menggali jenis komoditas bisnis para tenant sesuai dengan bakat dan tidak hanya sekedar terpaku pada minatnya.

Program Pengabdian Masyarakat berbasis IPTEKS Kewirausahaan (IbK) ini khalayak sasarannya adalah Siswa-Siswi Kelas XII SMAN 2 Kota Jambi yang merupakan siswa yang akan lulus SMA baginya tidak melanjutkan kebangku kuliah. Jumlah mitra ini ditetapkan dengan mempertimbangkan efisiensi dan intensitas pelaksanaan program. Mitra yang merupakan Siswa-Siswi Kelas XII SMAN 2 Kota Jambi. Jenis permasalahan yang ditangani dalam program IPTEKS Kewirausahaan (IbK) meliputi aspek produksi dan manajemen usaha. Aspek produksi dengan melatih Siswa-Siswi Kelas XII SMAN 2 Kota Jambi IPTEKS Kewirausahaan (IbK) memproduksi nugget dan abon dari daun singkong sedangkan manajemen usaha dengan mengadakan kerjasama dengan koperasi, warung, toko, pedagang di pasar, supermarket dan 
swalayan untuk pemasaran. Pada hakekatnya, kegiatan IbM ini solusi terhadap permasalahan yang dihadapi mitra melalui pendekatan secara terpadu, agar dapat meningkatkan nilai ekonomis daun singkong yang masih belum termanfaatkan secara optimal.

Akan tetapi, pendidikan di Indonesia belum dapat diasumsikan baik. Pendidikan di Indonesia ditengarai oleh sebagian pakar dianggap kurang relevan dengan kebutuhan pasar. Pasalnya, pendidikan tinggi lebih menitikberatkan pada pendidikan akademis ketimbang pendidikan vokasional yang menghasilkan tenaga kerja terampil. Alhasil, banyak lulusan yang tidak menguasai aspek keahlian yang sesuai dengan diharapkan lapangan kerja. Ada pun lulusan terbaik Perguruan Tinggi banyak yang memilih bekerja di luar negeri ketimbang di dalam negeri. Perlu dilakukan rekonstruksi terhadap pendidikan Indonesia sehingga misi mencetak manusia yang cerdas dan kompetitif di era global dapat tercapai. Umumnya, tenaga kerja di Indonesia adalah lulusan sekolah dasar dan tidak tamat sekolah dasar yang jumlahnya mencapai di atas 50\%. Selanjutnya, lulusan SMP 18,9\%, SMA 14,60\%, SMK 7,8\%, S-1 $4,6 \%$, dan diploma $2,7 \%$.

Kendati rendahnya tingkat pendidikan mempersempit akses untuk mendapatkan lapangan pekerjaan, kondisi di lapangan menunjukkan makin tinggi jenjang pendidikan, makin tinggi pula kecenderungan untuk bekerja pada pekerjaan yang diciptakan orang lain. Hal itu didapatkan dari hasil sensus penduduk berdasarkan kepemilikan pekerjaan diketahui bahwa sebagian besar lulusan perguruan tinggi memilih bekerja sebagai karyawan dan pegawai. Persentasenya mencapai $74 \%$. Hanya 22,6\% yang memilih jadi wirausaha. Sebaliknya, lulusan SD atau tidak tamat SD meski kesempatan menjadi buruh atau karyawan hanya 10,8\%, sekitar $65 \%$ justru memiliki pekerjaan milik sendiri.

Saat ini, setiap tahun Indonesia diperkirakan melahirkan 750 ribu sarjana baru. Jumlah itu akan terus bertambah setiap tahun sehingga jumlah angka pencari kerja pun akan semakin meningkat. Fenomena yang terjadi pun adalah penuhnya pengunjung bursa tenaga kerja yang sebagian besar pengunjungnya merupakan kalangan terdidik muda Indonesia yang menganggur. Apabila diasumsikan jumlah sarjana baru yang 750 ribu itu masing-masing wirausahawan yang dapat menyerap 10 tenaga kerja, maka ada 7,5 juta tenaga kerja yang terserap dan meningkat tiap tahunnya seiring sarjana baru yang meningkat pula.

Daya beli masyarakat Indonesia yang tinggi, bonus demografi yang melimpah serta pasar yang besar merupakan peluang Indonesia untuk berkembang dan maju. Hal ini menjadikan berwirausaha menjadi pilihan yang tepat dan menjanjikan dalam meningkatkan pendapatan serta menyumbang nilai yang besar dalam perkembangan pertumbuhan ekonomi negara. Bonus demografi tidak akan menjadi tagihan demografi apabila potensi ini dikembangkan dan dimanfaatkan dengan baik.

Untuk mencetak wirausahawaan muda yang sukses, perlu mulai diterapkan strategi yang komprehensif yang mengikat dengan pendidikan, pengalaman terjun langsung dan dukungan masyarakat. Pengembangan cara yang efektif untuk menumbuhkan pengusaha muda adalah dengan melibatkan peran pendidikan, masyarakat, orang dewasa serta komunitas wirausahawan dalam strategi keterlibatan ini.

Sistem pendidikan Indonesia cenderung mencetak lulusan bermental pegawai daripada mental wirausahawan. Hal ini didukung dengan pemikiran orang tua yang melulu mendewa-dewakan prestasi akademik anaknya. Saat mendapati anak mereka mendapat nilai ulangan yang jelek, mereka akan cenderung memarahi anaknya. Kebanyakan dari mereka sering mendoktrin mindset pikiran anak mereka apabila nilai akademik jelek akan susah mencari pekerjaan atau menjadi pegawai. Para orang tua harusnya dapat meluangkan waktu mereka untuk berdiskusi, mendengarkan serta mengarahkan apa keinginan anak mereka. Mereka tidak sadar bahwa di luar menjadi pegawai, dunia wirausaha sangat menjanjikan. Sistem pendidikan, pemikiran orang tua serta lingkungan yang demikian akan menciptakan anak-anak bermental pegawai. Sungguh tak terpikirkan, anak-anak diajarkan menjadi pegawai di perusahaan, tapi siapa yang mendirikan perusahaan itu jika bukan wirausahawan. Anak-anak, remaja sangat membutuhkan cukup waktu dengan orang dewasa agar dapat mendukung, mendorong serta membantu mereka mencari tahu siapa mereka, bagaimana dunia bekerja, dan apa peran mereka dalam masyarakat.

Agar dapat mencetak wirausahawan, elemen penting dalam pendidikan ini adalah pendidikan kewirausahaan. Idealnya, konsep kewirausahaan harus diintegrasikan ke dalam kurikulum dari Sekolah Dasar (SD) sampai pasca Sekolah Menengah Atas (SMA). Pentingnya pendidikan kewirausahaan ini disisipkan di awal karena pemuda mempunyai energi yang luar biasa sehingga dapat mengekspresikan 
kreatifitas dan inovasi mereka mulai usia yang sangat muda. Menunggu sampai SMA atau masuk Perguruan Tinggi akan terlalu terlambat. Pada pendidikan kewirausahaan hendaknya digabungkan kurikulum yang menarik dengan praktek eksperimental yang dapat membawa dunia nyata yang ada di luar ke dalam pembelajaran di ruang kelas. Sekolah dapat mengundang relawan dengan berbagai bisnis yang relevan dan latar belakang kepemimpinan untuk berbicara di depan kelas dan melatih para siswa mengembangkan ideide mereka.

Mendorong mimpi mereka. Hal ini mungkin metode klasik, tapi ketika siswa mengetahui kisah sukses wirausahawan, mereka akan terpana dan berapi-api ingin menjadi seperti mereka. Banyak siswa sudah memiliki ide untuk berbisnis dan hanya membutuhkan pemandu untuk mengarahkan mereka. Ketika siswa mendapatkan reward serta positive reinforcement, mereka akan merespons dan bersemangat untuk mencapai apa yang mereka inginkan. Siswa dapat diarahkan untuk menggali apa pun dalam kehidupan mereka sehari-hari dan memanfaatkan peluang-peluang yang ada di sekitar mereka. Dengan bantuan sumber daya dan pengarahan, ide-ide mereka dapat dengan serius diterapkan serta menempatkan rencana bisnis mereka ke dalam tindakan nyata. Hal yang dapat dilakukan pihak sekolah untuk mewadahi kegiatan kewirausahaan siswa adalah dengan membuat komunitas pecinta wirausaha serta dengan mengadakan ekspo kewirausahaan di sekolah yang dapat memamerkan usaha dan karya-karya siswanya. Kegiatan ekspo kewirausahaan ini dapat dibarengkan dengan pensi sekolah yang dapat menarik perhatian masyarakat luar untuk datang menikmati. Siswa pun dapat mengikuti ekspo kewirausahaan di luar sekolah. Kegiatan ini dapat merangsang siswa untuk menuangkan ide-ide kreatif inovasi mereka, memberi penghargaan terhadap usaha mereka serta dapat menjual produk, jasa, dan ketrampilan mereka. Lebihlebih jika di dalam masyarakat terdapat komunitas wirausahawan yang senantiasa welcome kepada anak-anak muda yang belajar berwirausaha. Anak-anak muda tersebut akan merasa dihargai dan bersemangat melakukan yang terbaik.

Pendidikan kewirausahaan sudah banyak digalakkan di jenjang Perguruan Tinggi di Indonesia, tak hanya di jurusan bisnis, di prodi pendidikan pun sudah dilaksanakan. Seminar kewirausahaan, ekspo kewirausahaan, bahkan pendanaan proposal kewirausahaan siswa oleh pihak Perguruan Tinggi menjadi hot trend belakangan ini. Belum lagi dukungan pemerintah yang terus berupaya untuk semakin memudahkan lingkungan bisnis agar kondusif bagi pelaku usaha, seperti menjanjikan kemudahan akses terhadap permodalan/pinjaman bank tanpa dibebani agunan kredit melalui program Kredit Usaha Rakyat (KUR) dan program-program lain berupa pelatihan ketrampilan, pendanaan Program Kreativitas siswa (PKM) dan lain sebagainya semakin mendukung usaha muda dan usaha baru untuk bergerak. Menilik dukungan keadaan yang demikian, siswa akan semakin dapat mengepakkan sayap di bidang kewirausahaan. Idealnya, memang untuk kalangan siswa hendaknya lebih banyak praktek agar mengerti keadaan pasar yang dituju. Siswa diharapkan semakin memanfaatkan waktu mereka menjadi siswa organisatoris. Dengan menjadi siswa organisatoris, peluang memperluas jaringan pun akan semakin terbuka lebar. Ketika mereka dapat membuka usaha, siswa dapat menggunakan jaringan mereka untuk merekrut karyawan, mendapatkan dukungan, atau menjelajahi pasar-pasar baru untuk produk dan layanan mereka. Networking merupakan kunci bagi pengusaha sukses.

\section{METODE PENELITIAN}

Dalam rangka untuk melaksanakan kegiatan ini, dilakukan survey terlebih dahulu tentang masalah yang berkaitan dengan pengembangan wirausaha siswa baik dari segi hambatan maupun manajemannya sehingga pemberdayaan diri para siswa untuk mewujudkan pengembangan wirausaha siswa menjadi lebih. Untuk itu tim pelaksana kegiatan pengabdian ini khususnya perwakilan dari perguruan tinggi yaitu LPPM Universitas Jambi berusaha untuk memberikan materi-materi penting berkaitan dengan pengembangan wirausaha siswa baik dari segi pengembangan jenis usaha maupun manajemennya dan kegiatan Tri Darma Perguruan Tingggi juga dapat diwujudkan dengan baik.

Metode yang digunakan dalam kegiatan ini adalah menggunakan metode ceramah, diskusi dan tanya jawab kemudian dilakukan evaluasi terhadap perkembangan wirausaha siswa dan perkembangan jenis usahanya. Metode seperti ini dapat meningkatkan motivasi siswa. Dengan adanya kegiatan ini dapat memajukan kegiatan-kegiatan ekonomi yang ada di sekolah sebagai pelaksanaan wirausaha untuk semangat berwirausaha khususnya di siswa kelas XIII SMAN 2 kota Jambi. 
Adapun tempat penyelenggaraan kegiatan ini akan dilaksanakan selama 6 bulan yaitu mulai survey, pelaksanaan dan laporan kegiatan mulai dari bulan Juni sampai Oktober 2018 di SMAN 2 Kota Jambi.

\section{HASIL DAN PEMBAHASAN}

Ipteks bagi Kewirausahaan ( $\mathrm{IbK}$ ) merupakan program baru di DP2M Dikti yang dirumuskan pada tahun 2009. Pada prinsipnya program $\mathrm{IbK}_{\mathrm{b}}$ mensubstitusi program sejenis sebelumnya, yaitu Pengembangan Budaya Kewirausahaan di Perguruan Tinggi (PBKPT), yang dirumuskan dan direalisasikan sejak tahun 1997. Program PBKPT yang dilaksanakan secara parsial tanpa adanya sinergi di antara setiap program (KWU, KKU, MKU, KBPK dan INWUB), menyebabkan tidak dapat mencapai misinya membentuk wirausaha baru dari kampus. Di samping itu, PT umumnya telah memiliki mata kuliah wajib atau pilihan Kewirausahaan dan Unit Penempatan Tenaga Kerja. Oleh karena itu, DP2M memandang perlu untuk merumuskan suatu program dengan misi yang sama, yaitu menghasilkan wirausahawirausaha baru dari kampus, namun melalui program terintegrasi dengan kreasi metode diserahkan sepenuhnya kepada penyelenggara $\mathrm{IbK}$. IbK dikelola sejumlah staf dari berbagai disiplin ilmu dan melaksanakan sejumlah kegiatan kreatif untuk menghasilkan wira usaha baru yang mandiri. Dalam kegiatannya, IbK juga dapat berkolaborasi melakukan kerjasama dengan lembaga-lembaga yang terkait dengan pengembangan kewirausahaan.

Misi program $\mathrm{IbK}$ adalah memandu PT menyelenggarakan unit layanan kewirausahaan yang profesional, mandiri dan berkelanjutan, berwawasan knowledge based economy. Sedangkan tujuannya adalah (1) menciptakan wirausaha baru yang mandiri, (2) meningkatkan keterampilan manajemen usaha bagi masyarakat industri, (3) menciptakan metode pelatihan kewirausahaan yang cocok bagi mahasiswa $\mathrm{PKMK} /$ mahasiswa wirausaha. Mengingat bahwa $\mathrm{IbK}$ suatu saat harus mandiri dan operasionalnya berkelanjutan, maka $\mathrm{IbK}$ diberi akses seperti halnya unit profit.

Dalam upaya menciptakan wirausaha baru mandiri, program $\mathrm{IbK}$ dapat dilaksanakan dalam bentuk pelatihan kewirausahaan, menempatkan mahasiswa untuk melaksanakan magang pada perusahaan yang mapan dan memfasilitasi mahasiswa berwirausaha. Pelatihan dilaksanakan untuk memberikan pengetahuan kewirausahaan, mendorong tumbuhnya motivasi berwirausaha, meningkatkan pemahaman manajemen (organisasi, produksi, keuangan dan pemasaran) dan membuat rencana bisnis atau studi kelayakan usaha. Kegiatan magang pada perusahaan dilaksanakan untuk memberikan pengalaman praktis kewirausahaan kepada mahasiswa dengan cara ikut bekerja sehari-hari pada perusahaan tersebut. Mahasiswa yang telah mulai berwirausaha dan mahasiswa PKMK, bisa menyempurnakan kegiatan kewirausahaan yang telah dilakukan sebelumnya, untuk meningkatkan usahanya. Unit layanan program IbK setiap tahun wajib membina 20 calon wirausaha yang seluruhnya adalah mahasiswa PKMK/mahasiswa yang merintis usaha baru. $\mathrm{IbK}$ diharapkan juga bersinergi dengan bidang kemahasiswaan perguruan tinggi untuk merekrut mahasiswa yang mendapatkan Program Kreatifitas Mahasiswa Kewirausahaan dan peserta kegiatan kewirausahaan yang didanai Direktorat Kelembagaan Dikti sebagai tenant. Luaran kegiatan IbK adalah (1) wirausaha baru mandiri per tahun yang siap berkompetisi di masyarakat. (2) $80 \%$ dari calon wirausaha tahun pertama menjadi wirausaha baru. Hasil program $\mathrm{IbK}_{\mathrm{K}}$ wajib diseminasikan dalam bentuk artikel dan dipublikasikan melalui jurnal/majalah internasional.

Kegiatan IbK dapat dilaksanakan maksimum 3 (tiga) tahun berurutan. Setiap tahunnya IbK wajib mengelola sebanyak 20 tenant. Jika misalnya ada 5 (lima) orang tenant telah menjadi wirausaha pada tahun pertama, maka tahun kedua $\mathrm{IbK}_{\mathrm{b}}$ wajib merekrut jumlah tenant yang sama, yaitu 5 (lima) orang. Demikian seterusnya sehingga $80 \%$ peserta awal menjadi wirausaha. Rencana kegiatan tahun pertama harus rinci, sedangkan tahun kedua dan ketiga boleh secara garis besarnya saja. Setiap tahun rencana harus dirinci dan dituangkan dalam laporan tahunan kegiatan, untuk dinilai kelayakan kelanjutannya. Dana PT digunakan untuk membiayai kegiatan manajemen IbK. Dalam kegiatannya juga terbuka peluang bagi lembaga mitra lain untuk bekerjasama dan/atau membiayai kegiatan yang dilaksanakan. Dana kemitraan lain dapat berupa bantuan lembaga perbankan, non-bank, hibah dalam atau luar negeri. Pencairan dana dilakukan dalam 2 tahap; tahap I $70 \%$ dan tahap II $30 \%$. 


\section{DAFTAR PUSTAKA}

Almar, Buchori, 2001, kewirausahaan, Bandung, Alfabeta. Alwisol. (2004). Psikologi Kepribadian. Malang : UMM Press.

Anderson, J,S,. Manz, C,C, \& Prussia, G,E. (1998). Self-leadership and performance outcomes: the mediating influence of self efficacy. Journal of Organizational Behavior, 19, 523-538.

Drucker, P.F, 1996, Konsep Kewirausahaan Era Globalisasi, Erlangga: Jakarta. Terjemahan

Dwi Riyanti, B. P. (2002). Factors Influencing The Succes of Small-Scale Entrepreneurs In Indonesia. Jakarta, Indonesia. Atmajaya Indonesia Catholic University.

Fadiati, Ari, M.Si., Purwana Dedi, M.Buss,. (2011). Menjadi Wirausaha Sukses. (cetakan kedua). Bandung. PT. Remaja Rosdakarya.

https://www.kompasiana.com/gilangramadani/menumbuhkan-wirausahawan-muda-indonesia-denganpendidikan-wiSMKrausaha-terintegratif_55283daff17e619f

$2 \mathrm{f} 8 \mathrm{~b} 45 \mathrm{~b} 7$

https://www.pressreader.com/indonesia/jawa-pos/20160118/281582354633232

Hisrich, R.D, Peters, M.P ., \& Shepherd, D.A, 2008. Enterpreneurship: Mc Graw hill, International edition.

Hendrojogi, (1999), Koperasi Azas-azas, Teori, dan Praktek. Rajagrafindo:

Kasmir. (2011). Kewirausahaan. (edisi revisi). Jakarta. Rajagrafindo Persada. Dr.Suryana, Yuyus, S.E., M.S, IR. Bayu Kartib, M.Si. (2010).

Kewirausahaan:Pendekatan Karakteristik Wirausahawan Sukses. (edisi pertama). Jakarta. Prenada Media Group.

Prihatin Dwi Riyanti, Benedicta, 2008, Metode Experintal Learning Berbasis pada peningkatan rasa percaya diri mampu, kreatif dan beresiko dalam mata pelajaran kewirausahaan untuk SMK, Jakarta, Unika Atma Jaya.

Suhartanto, Eko \& Ary Setijadi, 2010. Technopreneurship. Jakarta : PT.Elex Media Komputindo

Suryana, 2006. Kewirausahaan Pedoman Praktis:Kiat dan Proses Menuju Sukses. Jakarta : Penerbit Salemba 4

Suryana, M.Si. (2008). Kewirausahaan: Pedoman Praktis: Kiat dan Proses Menuju Sukses. (cetakan ketiga). Jakarta. Penerbit Salemba Empat. 